A C T A U N I V E R S T A T I S N I C O L A I C O P E R N I C I DOI:http://dx.doi.org/10.12775/AUNC_ZARZ.2017.052 ZARZĄDZANIE XLIV-NR4(2017)

Pierwsza wersja złożona 20.03.2017

Ostatnia wersja zaakceptowana 04.04.2017

ISSN (print) 1689-8966

ISSN (online) 2450-7040

Wojciech Leoński*

\begin{abstract}
THE INFLUENCE OF THE PROJECT ENHANCEMENT REGIONAL COMPETITIVENESS THROUGH CORPORATE SOCIAL RESPONSIBILITY ON THE IMPLEMENTATION OF CSR IN ENTERPRISES OPERATING IN THE AREA OF THE WEST POMERANIAN VOIVODESHIP
\end{abstract}

A b s t r a c t: This paper discusses the problem of influence of the project „Enhancement of regional competitiveness through Corporate Social Responsibility" on CSR implementation in West Pomeranian Voivodeship in Poland. The project was implemented by Polish Agency for Enterprise Development (PARP) under the Swiss-Polish Cooperation Programme. The first part of the paper characterizes the concept of CSR and the main assumptions of the project. The study also shows the level of interest in the project among Polish enterprises divided into voivodeships. In addition, a CSR analysis was conducted for the selected beneficiary of the program in West Pomeranian Voivodeship.

K e y w o r d s: Corporate social responsibility (CSR), strategy, West Pomeranian Voivodeship. K l a s y i k a j a J E L: L 21

\title{
INTRODUCTION
}

Corporate Social Responsibility (CSR) stands for the responsibility of a company for its actions. Socially responsible enterprises carry out actions in favor of environmental protection, support local communities, and also care for their employees. Many private and state organizations support and recommend enterprises to implement CSR. There are many financial and non-financial tools

\footnotetext{
* Address for correspondence: Wojciech Leoński, University of Szczecin, Faculty of Economics and Management, Institute of Management and Investments, ul. Mickiewicza 64, 71-101 Szczecin, e-mail: wleonski@wneiz.pl.
} 
providing support for entrepreneurs in implementing CSR. An example of such a tool is the "Enhancement of regional competitiveness through Corporate Social Responsibility" program executed by the government agency PARP, in terms of the Swiss-Polish Cooperation Programme. At this point a question should be asked whether this tool carries out its role and has an impact on forming society oriented and pro-ecologic attitudes among entrepreneurs of the West Pomeranian voivodeship.

The goal of the article is to analyze the "Enhancement of regional competitiveness through Corporate Social Responsibility" program in reference to enterprises from the West Pomeranian Voivodeship, and also to present good practices of the program's beneficiary from that voivodeship. The handled research subject has been executed with the use of the evaluation method, including: analyses of literature, reports, research papers and conclusions.

\section{THE ESSENCE OF CORPORATE SOCIAL RESPONSIBILITY}

Defining corporate social responsibility is not an easy task, as it is a multidimensional term. The problematic of CSR constitutes the interest for economists, sociologists, psychologists, and ethicists, which only points to its complexity. Many definitions of the concept of CSR have been created over the years. Currently, new definitions are being constantly created, and are formed by the academic environment, international and national organizations, or enterprises themselves. Only selected definitions, created in recent years, have been presented in the article. Their analysis allows to distinguish common fields and elements of the ideas. Thus, understanding the essence of CSR becomes easier.

The present-day CSR is a concept whereby business organizations consider the interest of society by taking responsibility for the impact of their activities on and other stakeholders as well as their environment. This obligation shows that the organizatios have to comply with legislation and voluntarily take initiatives to improve the well-being of their employees and their families as well as for the local community and society at large. CSR simply refers to strategies corporations or firms conduct their business in a way that is ethical and society friendly. CSR can involve a range of activities such as working in partnership with local communities, socially sensitive investment, developing relationships with employees, customers and their families, and involving in activities for environmental conservation and sustainability [Ismail, 2009, p. 199]. CSR can be also defined as a strategic, all-inclusive approach to doing business which takes into account social, environmental and employment issues. Corporate social responsibility is a business management concept where emphasis is placed on communication and building relations with stakeholders [Beyer, Leoński, 2016, p. 68]. Rudnicka [2012, p. 16] describes CSR as a pro-social 
activity aimed at undertaking or supporting socially-oriented initiatives, providing assistance, working for the benefit of other businesses, institutions and/or communities, regardless of the time needed for the benefits of this activity to appear. CSR also represents a plethora of responsibilities that a company should adopt in their policies and perform beyond legal requirements in response to the needs and expectations of its different stakeholders and society at large. The synthesis of the definitions stands that CSR requires a company to - consider the social, environmental and economic impacts of its business operations; and - be responsive to the needs and expectations of its customers, employees, investors, shareholders, and the local communities [Nasrullah and Rahim 2014, p. 15].

When defining CSR it is worth to quote the ISO 26000 norm which has been prepared by the International Organization for Standardization. It constitutes a guide concerning the corporate social responsibility, as it includes many guidelines for organizations. This norm features the most important fields of CSR which include: human rights, natural environment, involvement and development of societies, organizational order, consumer issues, honest business practices, managing human resources [International Organization for Standardization, 2010, pp. 5-8].

When analyzing the diversity of CSR definitions, it is possible to notice common features such as: the conceptualization of the environmental and economic aspects, meeting the needs of stakeholders, the voluntary character of socially responsible actions, the importance of communication and a dialogue with stakeholders, carrying out actions in accordance with ethical norms. That is why, it is important to notice that there is no one universal definition of CSR. CSR definitions complement one another, creating a realistic image of pro-ecologic and socially oriented actions in a contemporary enterprise. The definitions of CSR often emphasize the effect of synergy between the mentioned fields of CSR and the economic effects of running a business. To sum up, a socially responsible company is an entity, that takes into account social, environmental and professional aspects of running the business. It is a company, that feels responsible for its business and takes into consideration the needs of both external and internal stakeholders. A socially responsible company is also an ethical entity, both for its employees and customers.

\section{CHARACTERISTICS OF THE PROGRAM CONCERNING PROVIDING SUPPORT IN TERMS OF IMPLEMENTING CSR}

The Swiss-Polish Cooperation Programme, meaning the so-called Swiss Fund, is a form of non-returnable foreign support granted to Poland by Switzerland in terms of the Swiss help for 10 member states of the European Union, which became its part on May $1^{\text {st }} 2004$. The Polish Agency for Enterprise De- 
velopment (PARP) played the function of the Executing Institution for the "Enhancement of regional competitiveness through Corporate Social Responsibility (CSR)" project, executed in terms of the Swiss-Polish Cooperation Programme.

The discussed project consisted in three fields: building CSR competences (informative meetings and trainings carried out all over Poland), help in implementing CSR (organizing contests for companies implementing CSR and applying for a subsidy), communicating and promoting CSR by analyzing the effects of the implemented CSR projects. The article focuses on the support in implementing CSR solutions by executing pilot SME projects. The project included contests carried out for SME in which entrepreneurs applied for subsidies for projects concerning implementing CSR actions related to their on-going business activity. In terms of value, the contest for SME was the largest action concerning the project [PARP 2016]. When analyzing the selected aspects of this program it is possible to notice that it provides both direct and indirect support for entrepreneurs interested in CSR. Indirect support is related to the educational-training activity, while direct support concerns a non-returnable financial support for executing CSR projects. In terms of the discussed field, three contests have taken place. The first call for applications of entrepreneurs applying for financial resources for implementing CSR has ended on May $20^{\text {th }} 2013$, and the last one on February $8^{\text {th }} 2016$. The goal of the contest was to provide aid in the form of a non-returnable financial support for executing projects consisting in implementing CSR solutions. In this case, CSR has been interpreted as undertaking solutions by an entrepreneur, directly related with the operated business, which include social and environmental aspects. A company from the SME sector might have constituted the support in implementing CSR, under the condition of meeting all of the following requirements [PARP, 2016]:

1) had its headquarters in Poland, and in the case of being a natural person, resid-

ed in Poland (in the case of the first two contests);

2) started its business at least 6 months before the day of issuing the application for support;

3) has issued just one application in terms of the call for applications concerning providing support in implementing CSR;

4) has not received any prior support in terms of implementing CSR.

\section{LEVEL OF INTEREST IN THE PROGRAM IN RESPECTIVE VOIVODESHIPS}

The "Enhancement of regional competitiveness through Corporate Social Responsibility" project has had a national character. That is why, in the case of the two first contest, entrepreneurs from all over the country had the possibility to apply. Whereas, during the third contest, the possibility to apply was reserved 
for entrepreneurs from the following voivodeships: Podlaskie, Opole, Warmian-Masurian, Łódź, and Świętokrzyskie. The total allocation of funds in terms of the first call for applications concerning the competition for providing support in implementing CSR in SME was at PLN 5849 238.91. For the second call it was PLN 9379 570.65, and PLN 2366885.00 for the third one. Here it is worth to point to the level of interest concerning the project in respective voivodeships, presented in table 1 .

Table 1. Number of enterprises (applicants) applying for providing support in implementing CSR.

\begin{tabular}{|l|r|r|r|}
\hline \multicolumn{1}{|c|}{ Voicodeship } & $\begin{array}{c}\text { Applications for support } \\
\text { (CSR implementation) } \\
\text { formally correct }\end{array}$ & $\begin{array}{c}\text { Rejected applications for } \\
\text { support (CSR implementation) } \\
\text { formally incorrect }\end{array}$ & $\begin{array}{c}\text { All } \\
\text { applications }\end{array}$ \\
\hline Masovian & 58 & 15 & 73 \\
\hline Silesian & 36 & 11 & 47 \\
\hline Lódź* & 33 & 9 & 42 \\
\hline Lesser Poland & 31 & 6 & 37 \\
\hline Greater Poland & 30 & 8 & 38 \\
\hline Świętokrzyskie* & 28 & 5 & 33 \\
\hline Pomeranian & 26 & 12 & 38 \\
\hline Warmian-Masurian & 25 & 4 & 29 \\
\hline Lower Silesian & 23 & 11 & 34 \\
\hline West Pomeranian & 20 & 9 & 29 \\
\hline Podlaskie* & 16 & 3 & 19 \\
\hline Lublin & 16 & 1 & 17 \\
\hline Opole* & 15 & 3 & 18 \\
\hline Kuyavian-Pomeranian & 15 & 3 & 18 \\
\hline Lubusz & 15 & 6 & 21 \\
\hline Subcarpathian & 15 & 6 & 21 \\
\hline
\end{tabular}

* voivodeships, in which entrepreneurs had the possibility to participate in all three competitions Source: Own research based on PARP data

In the period between 2013 and 2016, most applications have been issued in the Masovian Voivodeship, and the least in the Subcarpathian Voivodeship. To a large degree, this results from the number of enterprises operating in these voivodeships. In the West Pomeranian Voivodeship, applications for subsidies to implement CSR have been issued by 29 enterprises. This voivodeship, together with the Swiętokrzyskie Voivodeship, is located on the $9^{\text {th }}$ position ina national scale (5.6\% of applications). However, two voivodeships that have been clas- 
sified higher in the ranking (Świętokrzyskie and Warmian-Masurian) had the possibility to participate in all three contests, while entrepreneurs from the West Pomeranian Voivodeship were able to take part only in the first two contests. It has to be stated that in the scale of the entire country, the interest in the program in the West Pomeranian Voivodeship was at a low level. Moreover, as many as $45 \%$ of the applications did not meet the formal requirements and were rejected. Only two voivedeships were worse in this shameful category: Lower Silesia $(48 \%)$ and Pomerania (46\%). The least incorrect applications were issued in the Lublin $(6 \%)$ and Warmian-Masurian $(16 \%)$ voivodeships. The high percentage of rejected applications may be surprising seeing how the requirements of the contest in terms of the "Enhancement of regional competitiveness through Corporate Social Responsibility" project were presented on PARP's website, and included the requirements which enterprises had to meet in order to apply for support in implementing CSR, provided from the resources of the Swiss-Polish Cooperation Programme. The requirements clearly defined i.a. the types of not supported projects, CSR costs and fields qualifying for support, and other criteria. This situation may partially result from the fact that all it took to reject the application was not to meet one formal requirement. A different reason behind the high ratio of rejected applications may be insufficiently familiarizing with the documents and requirements which had to be met when applying for the subsidy. Some applications might have been incomplete or lacked some information (lack of required attachments, empty fields, lack of a signature). The program and application includes specific actions and sub-actions. These include the descriptions of fields, criteria, and goals which should be achieved thanks to a given action. Before issuing the application, the entrepreneur should carefully verify it, whether the goal of the program corresponds with the goals which we want to achieve thanks to our investment, and whether exemplary types of CSR fields are at least remotely similar to what is assumed by the project. It seems that a solution to the problem of formal errors might have been taking advantage of the services of a proper adviser or familiarizing all of the requirements better. According to the data presented on PARP's website, the following constitute the most frequent formal errors in terms of preparing the subsidy application [PARP, 2009]:

- An incorrect PKD (Polish Classification of Activity) or EKD (European Classification of Activity) code defining the applicant's basic business,

- Incorrect business registration date,

- Incorrectly filled out, or empty fields in the table concerning the applicant's financial declaration,

- Product indicators exceeding above the accepted time frames,

- After calling for corrections, applicants change the application in an unauthorized manner, other than the one stated in the call, for example in terms 
of the value of indicators, prices concerning financing sources, contents of descriptive fields,

- Accounting errors in the application - in the table concerning the project's financial plan,

- In the "Project's financial plan" table, applicants do not take into consideration all of the quarters,

- Indicating the VAT tax both as an eligible and ineligible cost,

- The lack of a digital version of the application, the paper form differs from the digital application,

- Incorrectly assigning expenses from the category of overhead costs to the categories of other expenses.

When analyzing the entities applying for subsidies, it is worth also to present the number of entities which have been granted such a subsidy. As it has been emphasized before, many applications were rejected due to formal and factual errors. Image 1 presents the number of entities which have been granted financial support for implementing CSR.

Img. 1. Beneficiaries of the project with a division into voivodeships in the years 2013-2016

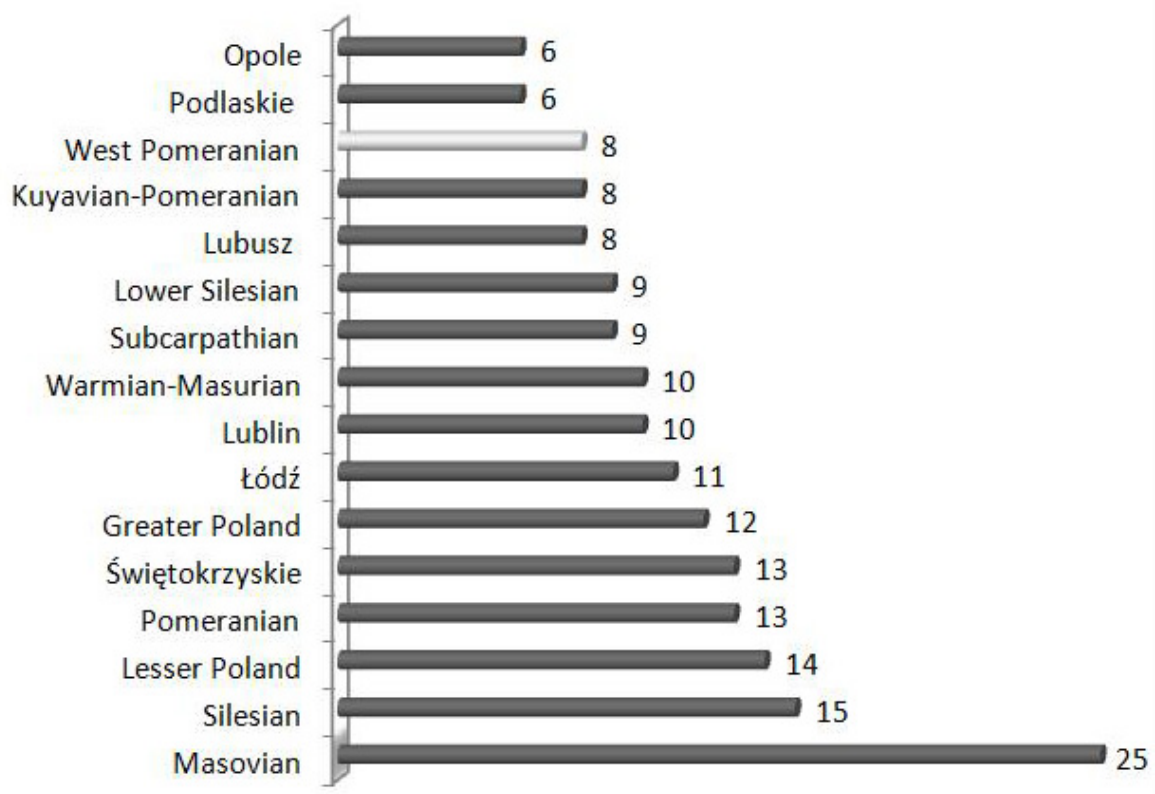

Source: Own research basing on PARP data

When analyzing data presented in image 1 it may be noticed that 177 entities from all over Poland took advantage of the "Enhancement of regional compet- 
itiveness through Corporate Social Responsibility" project. The most subsidies were granted in the Masovian Voivodeship (25) and the least in Podlasie (6) and Opole (6). 8 enterprises from the West Pomeranian Voivodeship were granted a subsidy to implement CSR, which constitutes $4,5 \%$ on a national scale. The average number of beneficiaries per voivodeship was 11 entities, therefore, it has to be stated that the West Pomeranian Voivodeship was below the average.

\section{CSR PRACTICES OF THE SELECTED BENEFICIARY OF THE PROJECT FROM THE WEST POMERANIAN VOIVODESHIP}

Subsidies to implement corporate social responsibility have been granted to a total of 8 entities in the years 2013-2016 in the West Pomeranian Voivodeship. These were such companies as: Dom Lekarski S.A., Horse Power Tuning Przemysław Grzeliński, Biuro Podróży INTERGLOBUS-TOUR, PRES-CON, Szczecin West Pomeranian Business School, Daniel Górski "Meridian 15", Cukiernicza Spółdzielnia Inwalidów SŁOWIANKA, Meridian 15S A. Bloch, T. Bloch. The author of the research has analyzed the CSR fields and tools of the Cukiernicza Spółdzielnia Inwalidów SŁOWIANKA, basing on data made available by the company on a website. Being a disabled workers co-operative, the idea of corporate responsibility is in a way a part of its nature. The information concerning CSR provided by the company are not classified basing on the 26000 norm, that is why the CSR actions of CSI SŁOWIANKA have been ordered in the below table.

Table 2. CSR actions at CSI SŁOWIANKA

\begin{tabular}{|l|l|}
\hline ISO 26000 field & CSR actions \\
\hline Organizational order & $\begin{array}{l}\text { Dialog and cooperation with stakeholders. } \\
\text { StOWIANKA actively works with many institutions, offices, and academ- } \\
\text { ic-research environments all over the country, such as: PFRON, Szczecinek } \\
\text { City Hall, Szczecinek District Starosty, Agricultural Market Agency, Ministry } \\
\text { of Economy, University of Lódz, Poznań University of Life Sciences, IN- } \\
\text { CHACO, IPS Technologia. Publishing information concerning CSR practices } \\
\text { online. }\end{array}$ \\
\hline Human rights & $\begin{array}{l}\text { Diversity at the workplace, people with disabilities constitute a significant } \\
\text { number of employees. Due to this, the company carries out a number of } \\
\text { actions in favor of supporting and the development of this group of people in } \\
\text { terms of the ZPFRON fund, an Individual Rehabilitation Program, or limiting } \\
\text { workplace barriers. }\end{array}$ \\
\hline
\end{tabular}




\begin{tabular}{|l|l|}
\hline Relations with employees & $\begin{array}{l}\text { By implementing an electronic system of surveys researching the level of } \\
\text { client satisfaction, the company may better understand their needs. } \\
\text { Financing medical consultations for employees conducting a program of } \\
\text { individual rehabilitation for the staff. } \\
\text { A rich benefits package. In terms of it, all employees of the SŁOWIANKA } \\
\text { company receive holiday vouchers twice a year, and their children packages } \\
\text { of sweets. Furthermore, individual loans for renovating or purchasing an } \\
\text { apartment are granted in terms of the Company Benefit Fund. Additional } \\
\text { service anniversary awards are granted to long-time employees. }\end{array}$ \\
\hline Environment & $\begin{array}{l}\text { All packages and waste, used office and electronic consumables, batteries, } \\
\text { and luminous tubes are diligently segregated by the company. } \\
\text { An optimization of the process of distribution by purchasing specialist soft- } \\
\text { ware, which as a result lowers the emission of fumes. } \\
\text { Exchanging the lighting in vast production halls with energy efficient LED } \\
\text { light bulbs. } \\
\text { Computer equipment meeting the Energy Star norms. An electronic doc- } \\
\text { ument flow system has been introduced. Implementing the technology al- } \\
\text { lowed for a significant reduction of paper used for internal communication. }\end{array}$ \\
\hline Honest market practices & \begin{tabular}{l} 
No information. \\
\hline Relations with consumers
\end{tabular} \\
$\begin{array}{l}\text { Keeping the International Food Standard. } \\
\text { Improving products by commissioning researching the products by profes- } \\
\text { sional laboratories. }\end{array}$ \\
\hline Social involvement & $\begin{array}{l}\text { Participation in charity actions, for example packages for orphans, partici- } \\
\text { pating in social dialogue sessions. }\end{array}$ \\
\hline
\end{tabular}

Source: Own research based on: http://www.slowianka.com.pl/ and Odpowiedzialność się opłaca, czyli CSR w MŚP, PARP, Warsaw 2015, pp. 88.

CSI Słowianka classifies CSR actions in such fields as the organization, employees, ecology, product quality. There is however, the lack of other fields resulting from the ISO 26000 norm, which does not mean that the company doesn't execute actions in these fields. As presented in Table 2, the company executed CSR practices in almost all fields of the ISO 26000 norm. Definitely most CSR practices are executed in the field of relations with employees. Thanks to the resources granted from the program to implement CSR, the company was able to engage stronger in pro-ecologic activity, which is confirmed by the practices presented in Table 2. It seems that in some fields the company could enhance its involvement, for example in the field concerning social engagement.

\section{CONCLUSIONS}

Implementing the concept of corporate social responsibility in enterprises is more and more popular, and at the same time necessary. CSR actions became a key field and a priority element of the policy of many companies. An important role in promoting the idea of CSR is played by various organizations, such as 
for example PARP, which offer factual and financial support for entities which decide to implement CSR. That is precisely the kind of support CSI Słowianka took advantage of, being one of the 8 beneficiaries from the West Pomeranian Voivodeship. Analyzing the Swiss-Polish Cooperation Programme it has to be pointed out that the interest in the program in the West Pomeranian Voivodeship, as well as other voivodeships, was not high, which can be seen in the number of applicants. Basing on the analysis of the selected enterprise, it may be concluded that implementing CSR strategies results in significant advantages for the company, its employees, and the surroundings within which it operates. Thanks to forming proper attitudes in most fields of corporate social responsibility, the company is more flexible, thanks to which it can better operate on the market which constantly undergoes changes. The company presented in the article may constitute a good example for other enterprises which want to operate in accordance with the assumptions of corporate social responsibility.

\section{REFERENCES}

Beyer K., Leoński W., (2016), Reporting as an important instrument of corporate social responsibility, Journal of corporate social responsibility and leadership, volume 3, issue 2, pp. $67-77$.

http://www.slowianka.com.pl/ [01.05.2017].

International Organization for Standardization, (2010), Discovering ISO $26000 \mathrm{http}: / / \mathrm{www} . i s o$. org/iso/discovering_iso_26000.pdf [28.06.2017].

Ismail M., (2009), Corporate social responibility nd its role in community development: an international perspective, The Journal of International Social Research Volume 2 / 9 Fall 2009, pp. 199-209.

Nasrullah N.M., Rahim M.M. (2014), CSR, Sustainability, Ethics \& Governance, Heidelberg, New York, Dordrecht, London, Springer.

PARP (2016), Konkurs o udzielenie wsparcia ma wdrożenie CSR, http://csr.parp.gov.pl/index/in$\operatorname{dex} / 2268$ [01.06.2017].

PARP (2009), Najczęściej popetniane błędy przy przygotowywaniu przez przedsiębiorców wniosków o dofinansowanie projektów, http://poig.parp.gov.pl/index/index/1269 [01.06.2017].

PARP (2010), Odpowiedzialność się opłaca, czyli CSR w MŚP, Warszawa.

Rudnicka A., (2012), CSR - doskonalenie relacji społecznych w firmie, Wolters Kluwer Polska, Warszawa.

WPLYW PROJEKTU ZWIECSZENIE KONKURENCYJNOŚCI REGIONÓW POPRZEZ SPOEECZNA ODPOWIEDZIALNOŚC BIZNESU NA WDROŻENIE CSR W PRZEDSIĘBIORSTWACH WOJEWÓDZTWA ZACHODNIOPOMORSKIEGO

Zarys treści: Artykuł porusza problem związany z wpływem projektu „Zwiększenie konkurencyjności regionów poprzez społeczną odpowiedzialność biznesu" na wdrażanie CSR w województwie zachodniopomorskim w Polsce. Projekt został zrealizowany przez Polską Agencję Rozwoju 
Przedsiębiorczości (PARP) w ramach Szwajcarsko-Polskiego Programu Współpracy. Pierwsza część artykułu dotyczy istoty koncepcji CSR, a także przedstawia główne założenia projektu. W artykule przedstawiono również poziom zainteresowania projektem wśród polskich przedsiębiorstw według poszczególnych województw. Dodatkowo przeprowadzono analizę narzędzi CSR dla wybranego beneficjenta programu w województwie zachodniopomorskim. Podjęty temat badawczy został zrealizowany za pomocą metody oceny, w tym: analizy literatury, raportów i opracowań wraz z wnioskowaniem.

Słowa kluczowe: społeczna odpowiedzialność biznesu, strategia, województwo zachodniopomorskie. 
